\title{
Value first, then price: the new paradigm of B2B buying and selling
}

\author{
Andreas Hinterhuber ${ }^{1} \cdot$ Todd C. Snelgrove $^{2} \cdot$ Bo-Inge Stensson $^{3}$
}

Received: 21 May 2020 / Accepted: 30 September 2020 / Published online: 24 March 2021

(c) The Author(s) 2021

\begin{abstract}
Most companies today take an inherently adversarial approach to buying and selling in industrial markets, thereby missing out on opportunities for joint value creation with customers and suppliers. Sales as well as procurement are too obsessed with price and not enough with value. In this paper we present a set of principles that put joint value creation at the centre of the relationship with customers and suppliers. With respect to customers, the value quantification capability is the most important competency of the sales function, i.e. the ability to translate a firm's competitive advantages into one quantified, monetary value reflecting both qualitative as well as quantitative customer benefits. With respect to suppliers, we call for the creation of new metrics, such as total value of ownership, reflecting innovation, management capabilities, sustainability, and other elements beyond quality, price, and delivery. With value quantification capabilities (sales) and total value of ownership models (procurement) the key element of relationship with both customers and suppliers is value first, then price.
\end{abstract}

\section{The problem}

Most companies today take an inherently adversarial approach to buying and selling in industrial markets, thereby missing out on opportunities for joint value creation with suppliers and customers. Procurement is relegated to an administrative role, as the sales function commoditizes the value that other functions-R\&D, marketing, operationshave created.

\section{The solution}

We present a set of principles that enable companies to put joint value creation at the center of their relationships with suppliers and customers.

Andreas Hinterhuber

andreas.hinterhuber@unive.it

Todd C. Snelgrove

todd@expertsinvalue.com

Bo-Inge Stensson

bo-inge@stenssonperformancegroup.com

1 Department of Management, Ca' Foscari University of Venice, Venice, Italy

2 Experts in Value, Clarkston, MI, USA

3 Stensson \& Associates AB, Glumslöv, Sweden

\section{The benefits}

Focusing first on value, then on price, our research suggests, leads to higher profitability. The procurement function, typically regarded as a cost center, becomes a source of innovation and a driver of good corporate citizenship. The sales function, by emphasizing first value and then price, transforms an adversarial relationship with customers into a collaborative relationship. As a result, customers, suppliers, and society at large benefit.

\section{Introduction}

Allow us to take you on a tour, meeting your sales managers as they negotiate prices with their customers. You will see buyers who are either supremely cool or excited, but they never quite seem real-as an observer, you wonder if you are the only one to notice-and sellers who are under visible pressure. Offers fly back and forth until an agreement is reached. Buyers seem happy about the discount, and sellers seem to be busy calculating their commissions. Who won? Difficult to tell.

Follow us again to meet your buyers as they negotiate prices with their suppliers. "You can go lower!" you feel tempted to shout. "I have seen this before," you hear yourself saying, "not just now, but a hundred and a thousand times before. Did nothing change over the past decades?" And 
indeed, for most companies in industrial markets, the answer is no: The price is still the main element of buying and selling in industrial markets-little seems to have changed. The approach typically taken by purchasing and sales executives vis-à-vis their suppliers and customers is best summarized in one word: adversarial.

This need not be. Our experience at SKF, the US \$9 billion manufacturer of industrial bearings and other components based in Gothenburg, Sweden, and the research we conducted with numerous other B2B companies (Hinterhuber 2017) lead us to suggest a way to break from this vicious cycle of buying and selling in industrial markets.

Let us accompany one of the co-authors of this article, Todd Snelgrove, then SKF's vice-president of value, on a sales encounter with a global steel company purchasing industrial bearings. Industrial bearings are, to the lay person, commodities - apparently interchangeable steel used as parts of wheels and other moving objects. SKF's product has a list price of $\$ 15$ (all numbers are disguised), whereas the product of its main competitor has a list price of $\$ 10$. How would negotiations evolve within your own company? Most purchasing and sales executives we quiz during our workshops suggest that, depending on circumstances, both parties would compromise at around $\$ 12$ in an attempt to seal a deal, with a few thousand dollars worth of services such as training or installation thrown in for free.
This is, however, not the case in a typical sales encounter with SKF sales managers. Typically, purchasing managers-well-trained, aggressive industrial purchasing managers-pay the list price of $\$ 15$. The reason is that, in a sales encounter with SKF, the discussion is first on value, then on price. The sales encounter is centered first on what the customer gets and only thereafter on what the supplier gets. This, we believe, is one simple reason why SKF is able to differentiate what many other companies would view as a commodity. [See Fig. 1: "First Value, Then Price: Value Quantification Drives Profits at SKF" (Snelgrove 2013)].

SKF's product carries a price premium of $50 \%$ over the product of its key competitor. Yet, sales managers at SKF are able to demonstrate to customers that customers end up paying less and being better off by purchasing from SKF. The company presents its price premium as an investment required to obtain clearly defined monetary benefits. In this case, an investment of $\$ 5$ (i.e., the price difference between the two products) will lead to quantified customer benefits of $\$ 30$ (i.e., the incremental performance advantage of SKF's product, calculated via longer uptime, higher reliability, faster installation, lower lubrication costs, and other elements).

SKF and other high-performing companies turn sales negotiations from a discussion about price to a visualization of value and present their competitive advantages in

Price vs. total costs

It's about measuring all the factors

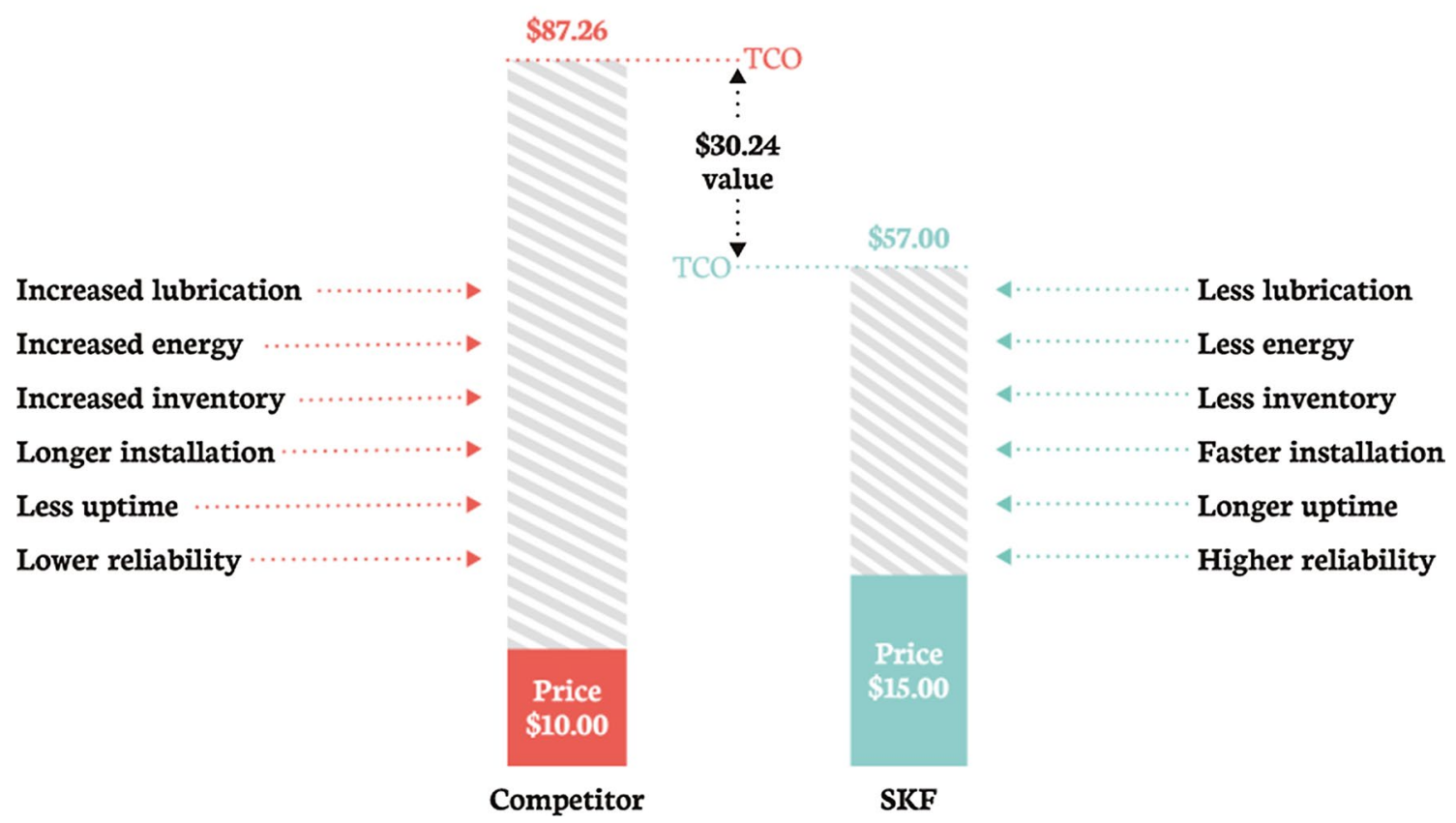

Fig. 1 First value, then price: value quantification drives profits at SKF (Snelgrove 2013) 
Past and future best practices of B2B buying

\begin{tabular}{|c|c|c|}
\hline & Past best practice & Future best practice \\
\hline $\begin{array}{r}\text { Main purchase } \\
\text { criteria }\end{array}$ & Price, quality, delivery & $\begin{array}{l}\text { Quality, cost, delivery, innovation, management (QCDIM) } \\
\text { Total cost and total value of ownership } \\
\text { Performance-based contracts }\end{array}$ \\
\hline $\begin{array}{l}\text { Consideration } \\
\text { of soft factors }\end{array}$ & Generally not & $\begin{array}{l}\text { Yes: sustainability, risk, agility and innovation are } \\
\text { key differentiators for suppliers }\end{array}$ \\
\hline $\begin{array}{l}\text { Relationships } \\
\text { with suppliers }\end{array}$ & $\begin{array}{l}\text { Adversarial BTI/BTU } \\
\text { (bring them in, beat them up) }\end{array}$ & $\begin{array}{c}\text { Collaborative, objective is joint value creation } \\
\text { Win-win; shared KPIs }\end{array}$ \\
\hline Time horizon & Short term & Long term \\
\hline $\begin{array}{l}\text { Inter-company } \\
\text { collaboration }\end{array}$ & $\begin{array}{l}\text { Limited - purchasing department } \\
\text { operates largely autonomously }\end{array}$ & $\begin{array}{l}\text { High - cross functional collaboration with sales, } \\
\text { marketing, R\&D, manufacturing, finance and suppliers }\end{array}$ \\
\hline Contribution & Tactical, low impact & Strategic, high impact \\
\hline $\begin{array}{r}\text { Main explicit } \\
\text { assumption }\end{array}$ & Products are commodities & Suppliers are a source of innovation \\
\hline $\begin{array}{r}\text { Main implicit } \\
\text { assumption }\end{array}$ & Companies compete against each other & Eco-systems compete against each other \\
\hline Capabilities & Product and price & $\begin{array}{l}\text { Understanding both supplier and customer value } \\
\text { propositions, end-to-end value chain knowledge }\end{array}$ \\
\hline
\end{tabular}

Fig. 2 The new rules of purchasing in B2B

a language that every purchasing manager understands: money, i.e., quantified customer benefits (Fig. 2).

We contend that if SKF is able to get paid for value by selling an apparently commoditized product carrying a price premium of $50 \%$ over competition, so should other companies with products that are frequently more differentiated than those of SKF. Our combined practical experience in $\mathrm{B} 2 \mathrm{~B}$ selling and buying and the research we conducted provide a roadmap for tackling this challenge.

As the example above suggests, best practices within companies such as SKF differ from approaches other companies typically take: compromise on price to get the deal. The focus on value versus price is an important one among many other elements: Our premise is that, in the future, the need for collaborative value creation with customers is so pervasive that it will transform the way B2B companies buy and sell. In other words, the rules for buying and selling in the future are being rewritten, and a number of companies-SKF among them-allow us a glimpse of future best practices. We sketch out what could be called the new rules of buying and selling in B2B markets, starting with the former.

\section{B2B buying in the future: about ecosystems and innovation}

In industrial buying, best current and best future practices differ markedly. (See "The New Rules of Purchasing in B2B" for an overview.)

Today, B2B procurement is concerned about price, quality, and delivery—soft factors are typically not considered. Relationships with suppliers are adversarial. In the global car industry, for example, studies measuring the quality of 
relationships between suppliers and manufacturers not only find that GM and Chrysler receive the lowest ratings on trust while being seen as the most demanding in terms of expected price concessions by their suppliers; these studies also find that best-in-class companies such as Porsche or Toyota do not score significantly better on these criteria (Supplier Business 2009). Adversarial relationships with suppliers are pervasive, even among companies that today are regarded as best-in-class. Relationships with suppliers are thus mostly short term, and the procurement department today operates largely autonomously. This inherently limits its impact on overall company priorities to a tactical contribution at best. Implicitly, the procurement function today seems to treat every item on its shopping list as a commodity: Some companies do so quite explicitly. Shell's purchasing guidelines read, "Within Shell we do not differentiate between commoditised and non-commoditised products and services and consider all markets for which there is more than one supplier a commodity market" (Shell 2006).

Fritz Henderson, chief operating officer of GM at that time, summarized the company's aspiration as "GM builds vehicles that people want to buy" (Henderson 2009). The statement is trite. Most companies underestimate the monumental challenges that $\mathrm{B} 2 \mathrm{~B}$ procurement faces if it is to become a significant contributor to overall company success.

What are these challenges, then? Put simply, CEOs want more from procurement than price, quality, and delivery. CEOs demand innovation, sustainability, and ideas. The bombshell dropped, we contend, in June 2015 when six of the largest European oil and gas firms called for a globally coordinated price to reduce carbon-dioxide emissions. Take note: Heavy polluters were not the only ones to shoot for a green revolution. In September 2015, Siemens, the German industrial giant, announced the goal of becoming the first major industrial company to achieve a net-zero carbon footprint by 2030. This requires, among other monumental changes, a $50 \%$ reduction in carbon-dioxide emissions and investments of over US \$100 million (Siemens 2015).

The evidence is very compelling: The world and the strategic priorities of companies are changing, and the procurement function needs to drive this change. Profit or shareholder value maximization is not enough: Companies need to make a contribution beyond satisfying the requirements of shareholders, customers, and employees. As lofty as it may sound, the goal is to make the world a better place and procurement, responsible essentially for everything that comes in, needs to live up to this aspiration.

Among the characteristics that characterize future best practices in $\mathrm{B} 2 \mathrm{~B}$ purchasing are a focus on innovation and management capabilities, in addition to quality, price, and delivery. This inevitably means that soft factors are the new hard factors: sustainability, risk, agility, co-innovation, capacity management, supply chain transparency, and supplier labor standards are very important elements that cutting-edge purchasing managers consider in supplier selection. This inevitably shifts the time horizon from a short-term adversarial relationship to a long-term, collaborative relationship with suppliers aimed at joint value creation. The implicit assumption is that suppliers are precisely the opposite of manufacturers of commodities: Suppliers are a potential source of innovation that savvy purchasing managers leverage to their advantage. This is driven by the recognition that competition is manifest not only at the level of the individual company, but that it happens increasingly at the level of ecosystems (Hinterhuber and Nilles 2021). In a nutshell, supply chains and ecosystems compete against each other, not only companies.

Apple is an obvious example, but SKF, a manufacturer of industrial components, may also serve as illustration: Through subsidiaries, alliances, and acquisitions, SKF has developed a tight network of support and knowledge partners-including research institutions-that help its industrial customers in productivity improvements. In line with the company's vision-to equip the world with SKF knowledge - the focus of this tight network is knowledge creation to drive customer profitability. SKF's ecosystem thus acts as a powerful choice driver for industrial customers.

\section{B2B selling in the future: first value, then price}

B2B selling is likewise undergoing a major change. (See Fig. 3: "The New Rules of Selling in B2B," which summarizes current versus future best practices in industrial selling.)

Selling today is, we learn, about communicating unique selling points (USPs) to customers. Sellers promise results to customers. The primary contact of B2B sellers is the procurement function. Sellers follow the mantra of cutting-edge marketing textbooks that present a dichotomous choice for profitable marketing strategies (Kotler and Keller 2011): skimming (high price, low volume) or penetration (low price, high volume). Discounts are the key selling tool. Sales force compensation is linked to profit or revenue targets. The main implicit assumption is that differentiation is difficult in an environment shaped by aggressive purchasing managers who are increasingly selecting suppliers based on price. In order to mitigate the impact of price-sensitive customers, today the best-performing sales organizations concentrate on forging relationships with their customers.

This is, we think, the world of selling as we know it. As the experiences of the best practice companies in our research suggest, selling is being radically transformed. In the future, selling is not at all about selling USPs—-who says, after all, that they actually improve customer profitability? 
Past and future best practices of B2B selling

\begin{tabular}{|c|c|c|}
\hline & Past best practice & Future best practice \\
\hline $\begin{array}{r}\text { Main selling } \\
\text { points }\end{array}$ & USPs (unique selling points) & Documented and quantified customer value \\
\hline Results & Promised & Guaranteed \\
\hline Key contacts & Narrow: mostly purchasing & Broad: can include senior management \\
\hline Key goals & High price or high market share & High price and high market share \\
\hline $\begin{array}{l}\text { Main tactical } \\
\text { selling tool }\end{array}$ & Discounts & $\begin{array}{l}\text { Guaranteed performance metrics } \\
\text { Value calculators }\end{array}$ \\
\hline $\begin{array}{r}\text { Sales force } \\
\text { compensation }\end{array}$ & Linked to company revenues or gross margins & Linked to customer profit improvements \\
\hline $\begin{array}{l}\text { Main explicit } \\
\text { assumption }\end{array}$ & Buyers are price sensitive, products are commodities & $\begin{array}{l}\text { Commodities do not exist } \\
\text { Co-innovation with customers }\end{array}$ \\
\hline $\begin{array}{l}\text { Main implicit } \\
\text { assumption }\end{array}$ & Selling is about relationships & Selling is about business partnerships \\
\hline
\end{tabular}

Fig. 3 The new rules of selling in B2B

Selling is all about creating, quantifying, and documenting value to customers. Paula Gildert, then VP Global Head Strategic Sourcing at Novartis Pharma, has the following advice for any sales manager knocking on the company's doors: "Suppliers often don't come to us with a business case. But it's what we want. Sell your value in our numbers to get our attention. But if you can't quantify your value, don't be surprised at the failure of procurement to do so" (Snelgrove 2018, p. 252).

Witness SKF's Documented Solutions Program, which guarantees performance outcomes to customers and allows SKF to achieve premium prices vis-à-vis customers. This means results are not promised-results are guaranteed (Hinterhuber and Snelgrove 2020).

As the introductory example illustrates, in this case SKF and its customers both win. Metso, a technology supplier to the mining industry that evolved into Metso Outotec, is another pertinent example. "Expect results" was the company's tagline as a stand-alone company. Perttu Louhiluoto, President of the Mineral Services business area, notes that "suppliers need to be able to demonstrate and quantify the economic value of their offering beyond cash cost" (Louhiluoto 2017:10). Consequently, the company's CEO stresses the importance of "value quantification to the customer" noting that a solid understanding of customers' business enables the company "to quantify the business impact for the customer" (Kähkönen 2012:21). The increased importance of value quantification as a new capability of sales managers is reflected also in changes in the company's service offering: traditionally, Metso - but many other companies as well - offered "break-fix support", now the company is offering consulting contracts that optimize total cost of ownership and performance-based contracts that optimize customer operations (Silvennoinen 2014:20). Simplifying a bit, in these cases the service offering evolves from "done to" to "done with" to, finally, "done for" the customer. In the latter two cases, value quantification capabilities are of course of central importance. This approach to selling also allows a company to overcome the false dichotomy between high price and high market share: SKF, like Apple, is a market share leader and premium price producer at the same time. A focus on value enables high market share and premium prices to coexist.

Sales force compensation is linked not only to profit or revenue goals - these are, after all, internal indicators-but it is increasingly linked to outcomes that matter to customers, such as customer profit improvements or customer satisfaction. Implicitly, these companies feel very strongly that 
commodities do not exist. There is no product that cannot be differentiated. Shell, for example, illustrates that even a tradable commodity like gasoline can be differentiated, as in the highly successful introduction of V-Power (Hinterhuber 2016). The end result is that selling is about forging business partnerships with customers.

International logistics company DHL is a superb example. Pascal Kemps, sector head for passenger vehicles, frequently observes that the shipping operations of large customerse.g., global car manufacturers-are not optimized: When customers ask DHL and its competitors to submit a quotation, competitors will submit a proposal for, for example, 80 containers, as specified in the bidding documents. DHL, by contrast, typically will suggest freight optimization first, which means DHL ends up selling less (Hinterhuber and Kemps 2017). DHL quotes a price for 70 containers, for example, and highlights the steps to implement route optimization. This reduces revenues short term: "You need to make an investment to service a customer in order to achieve a longer-term sustainable success" Hinterhuber and Kemps 2017, p. 173). This sacrifice, Kemps suggests, builds invaluable trust with customers.

Forging partnerships requires, as the experience of DHL suggests, a cultural change. In Japan there is a beautiful expression: 'You have to be prepared to sit on a rock for three years,' observes Kemps, "which means that sometimes you have to be in a difficult, painful situation before you get results. I know that's difficult for many of my colleagues, but fortunately I' $m$ in an organization where it's understood that things may take time and it's accepted that sometimes you need to make an investment to service a customer in order to achieve a longer-term sustainable success. I' $m$ well aware that that's not the case in all organizations." (Hinterhuber and Kemps 2017, p. 173). Accordingly, DHL links sales force compensation to customer-related outcomes, such as profit improvements or customer satisfaction, and not only to company-related outcomes, such as sales or margin budgets.

The dual focus on value in both purchasing and selling allows SKF and other companies to thrive in a very competitive environment. In a stagnating environment, SKF, for example, has grown substantially vis-s-vis competitors. The procurement and supply chain functions have taken a proactive stance, moving from knowledge and compliance toward commitment and contribution as good corporate citizens. The performance has been honored as best in class by the Dow Jones Sustainability Index.

More broadly, several independent, quantitative studies with hundreds of respondents in B2B conclude that companies that sell on value are substantially more profitable than companies that sell on costs (Hinterhuber 2017; Hogan 2008; Liozu and Hinterhuber 2013; Nagle and Müller 2018) and that companies buying on total cost of ownership are again substantially more profitable than companies buying on price (Manufacturers Alliance for Productivity and Innovation 2012).

Buying and selling in B2B is not a zero-sum game: Customers, suppliers, and the society at large benefit from a joint focus on value and innovation occurring at the extreme ends of the organization-in buying and selling. Putting value ahead of price transforms a traditionally adversarial relationship into a collaborative partnership that unleashes profits and innovation.

Funding Open access funding provided by Università Ca' Foscari Venezia within the CRUI-CARE Agreement.

Open Access This article is licensed under a Creative Commons Attribution 4.0 International License, which permits use, sharing, adaptation, distribution and reproduction in any medium or format, as long as you give appropriate credit to the original author(s) and the source, provide a link to the Creative Commons licence, and indicate if changes were made. The images or other third party material in this article are included in the article's Creative Commons licence, unless indicated otherwise in a credit line to the material. If material is not included in the article's Creative Commons licence and your intended use is not permitted by statutory regulation or exceeds the permitted use, you will need to obtain permission directly from the copyright holder. To view a copy of this licence, visit http://creativecommons.org/licenses/by/4.0/.

Note: Part of this research was undertaken previously while Andreas Hinterhuber, Todd Snelgrove and Bo-Inge Stensson were working in different roles: Andreas Hinterhuber, Partner, Hinterhuber \& Partners; Todd Snelgrove, Vice President Value, SKF; Bo-Inge Stensson, SVP Group Procurement, SKF.

\section{References}

Henderson, F. 2009. Re-inventing GM: GM investor presentation. www.autonews.com/assets/PDF/CA59644122.PDF. Accessed 30 Aug 2014.

Hinterhuber, A. 2016. The six pricing myths that kill profits. Business Horizons 59 (1): 71-83.

Hinterhuber, A. 2017. Value quantification capabilities in industrial markets. Journal of Business Research 76: 163-178.

Hinterhuber, A., and P. Kemps. 2017. Interview: the ring of truthvalue quantification in B2B services. In Value first, then price: Quantifying value in business markets from the perspective of both buyers and sellers, ed. A. Hinterhuber and T. Snelgrove, 161-177. Abingdon: Routledge.

Hinterhuber, A., and M. Nilles. 2021. Digital transformation, the holy grail and the disruption of business models. Business Horizons, in press. https://doi.org/10.1016/j.bushor.2021.02.042.

Hinterhuber, A., and T. Snelgrove. 2020. The present and future of value quantification. Journal of Creating Value 6 (2): 295-303.

Hogan, J. 2008. Building a world class pricing capability: Where does your company stack up? Cambridge: Monitor Group Perspectives.

Kähkönen, M. 2012. Creating long-term value, Metso Capital Markets Day presentation, 11 December, Vantaa (Finland).

Kotler, P., and K.L. Keller. 2011. Marketing management, 14th ed. Upper Saddle River: Prentice Hall.

Liozu, S., and A. Hinterhuber. 2013. Pricing orientation, pricing capabilities, and firm performance. Management Decision 51 (3): 594-614. 
Louhiluoto, P. 2017. Three horizons of profitable growth, Metso Capital Markets Day Investor presentation, 1 June, Vantaa (Finland).

Manufacturers Alliance for Productivity and Innovation. 2012. Approaches towards purchasing on total cost of ownership. Arlington: A MAPI Council Survey.

Nagle, T., and G. Müller. 2018. The strategy and tactics of pricing: A guide to growing more profitably (6th ed.). New York, N.Y.: Routledge.

Shell. 2006. Shell Procurement Guide to Online Bidding. quoted in: Effective strategies for dealing with procurement, Huthwaite International, 2008.

Siemens AG. 2015. Siemens to be climate neutral by 2030: Siemens press release, Munich 22 September.

Silvennoinen, J. 2014. The leader in value-adding services, Metso Capital Markets Day Investor presentation, 26 November, Amsterdam (The Netherlands).
Snelgrove, T. 2013. Creating Value that Customers Are Willing and Able to Pay For Presentation at the Product Management Forum of the Manufacturers Alliance for Productivity and Innovation (MAPI) Rosemont, IL (USA).

Snelgrove, T. 2018. Creating, calculating and communicating customer value: how companies can set premium prices that customers are willing and able to pay. In Innovation in pricing: Contemporary theories and best practices (2nd ed.), ed. A. Hinterhuber and S. Liozu, 244-256. New York, NY.: Routledge.

Supplier Business. 2009. 2009 OEM-Supplier Relations Study, Planning Perspectives International. http://www.autonews.com/assets/ PPT/CA66291725.PPT. Accessed 15 July 2015.

Publisher's Note Springer Nature remains neutral with regard to jurisdictional claims in published maps and institutional affiliations. 